\title{
The Impact of Educational Investment on Sustainable Economic Growth in Guangdong, China: A Cointegration and Causality Analysis
}

\author{
Liping Liao ${ }^{1}$, Minzhe Du ${ }^{1}{ }^{\mathbb{D}}$, Bing Wang $^{1}$ and Yanni Yu ${ }^{2, *}$ \\ 1 Department of Economics, Jinan University, Guangzhou 510632, China; liping_liao@163.com (L.L.); \\ minzhe_du@126.com (M.D.); twangb@jnu.edu.cn (B.M.) \\ 2 Institute of Blue and Green Development, Shandong University, Weihai 264209, China \\ * Correspondence: yayabaobei@naver.com
}

Received: 26 December 2018; Accepted: 28 January 2019; Published: 1 February 2019

\begin{abstract}
Education, as an investment in human capital, is regarded as an important determinant of sustainable economic growth [1,2]. The purpose of this study is to explore the cointegration and causality between the investment in education and sustainable economic growth in Guangdong province by using the panel data of 21 cities from 2000 to 2016 . We construct a variable intercept panel data model with an individual fixed effect based on the Cobb-Douglas production function, estimating the contribution of the investment in education to economic growth by introducing lags. The findings show the existence of the feedback causality between education and sustainable economic growth. Also, the results reveal that the local financial investment in education plays a positive and statistically significant role in promoting sustainable economic growth. However, the contribution of the local financial investment in education to economic growth varies in different areas. The investment in education in the Pearl River Delta region have the most obvious pull effects on its regional economy, whereas the Western region takes the second place. Meanwhile, the local financial investment in education for its role in promoting economic growth obviously has a two-year hysteresis effect. These findings have important implications for Guangdong's solution to the imbalance between regional educational investment and sustainable economic growth.
\end{abstract}

Keywords: educational investment; sustainable economic growth; cointegration; causality; hysteresis effect

\section{Introduction}

Education can increase the human capital of the labor force, which will improve labor productivity growth and higher levels of economic growth [3]. Education can create a class of educated leaders to fill vacancies in governmental services, public corporations, private domestic and foreign businesses, and professions [4]. After thirty years of reform and opening, as the bellwether, Guangdong province has made remarkable achievements in economic development. It is obvious that Guangdong province made full use of its superior geographical position, special policy support, foreign trade advantage, and other favorable factors to create its brilliant achievement. However, some people ignore the effect of education in promoting economic growth, especially the contribution of the educational investment to the economic development in Guangdong province. Under the guidance of the government, Guangdong province has paid more and more attention to the importance of education. In 2017, the general public budget education funds in Guangdong province were far ahead, ranking first in the country with 252.255 billion yuan. The secretary of the Party of Guangdong province pointed out that Guangdong province will be created as the educational upland of Southern China, and emphasized that the educational investment is worthy because education will return more. The expansion of 
education can provide all kinds of training and education that would promote literacy and basic skills. Even though alternative investments in the economy could have generated greater growth, this would not detract from the important contributions, noneconomic as well as economic, that education can make and has made to promoting aggregate economic growth [4].

Take the twelve-year national education in Guangdong as an example, in the Western region, the Eastern region, and the Mountainous region of Guangdong province, the local governments are devoted to the construction of nine-year compulsory education. We take Shanwei, Yangiang, and Qingyuan as representatives of the Western region, the Eastern region, and the Mountainous region of Guangdong province, respectively. Yangjiang tried its best to improve the reconstruction project of students' living facilities in rural schools in the compulsory education years and Fifty-Students-Class-Scale Project [5] during the compulsory education years. Shanwei went on the Education Tail-cut Project [6], and intensified the sense of responsibility of counties, towns, streets, villages, and schools to reduce the compulsory education dropout rate. Qingyuan made great effort in the implementation of the Compulsory Education Law, and carried out daily inspection of the Compulsory Education Law in primary and secondary schools in the city in order to consolidate the achievement of nine-year compulsory education which has been made. On the contrary, in the Pearl River Delta, compulsory education construction has been fully accomplished. At the same time as improving the system of compulsory education, the government spared no effort to enhance the development of senior high school education. For example, the government of Dongguan took on board all expenses of the senior high school in the city, and Foshan increased the investment of government, and committed to characterize and internationalize the development of ordinary senior high schools. At the same time, it accelerated the development of ordinary high school education of high quality. The degrees of high quality of ordinary senior high school of the whole city are up to $100 \%$ in 2010. Todaro and Smith [4] also pointed out that the expansion of education can create a more productive labor force and endow it with increased knowledge and skills, and provide widespread employment and income-earning opportunities for teachers, schools, and workers. The important role of educational investment in promoting economic development is undeniable.

As mentioned above, different regions have different levels of investment in education due to differences in economic levels and local government policies. According to the 13th Five-Year Plan for Education Development in Guangdong province (2016-2020), Guangdong should accelerate the development of education in the eastern and western regions of Guangdong and increase the transfer of education in the eastern and western regions, thus providing a strong impetus and support for Guangdong to implement the innovation-driven development strategy and sustainable economic growth. Therefore, this study attempts to explore the impact of educational investment in these regions on economic growth and the differences among regions. Our empirical results show that in the past decade or so, educational investment in Guangdong has indeed played a significant role in the sustainable growth of the region's economy. However, regional differences in education impact still exist. Moreover, the effect of investment in education on sustainable economic growth is lagging.

The rest of the paper is organized as follows. The next section provides a brief literature review on this topic. Section 3 introduces the economic theory model and explain our model choice used in this study. Section 3 also describes the sources of data and processing. Section 5 dwells on the panel data model tests about educational investment and economic growth, such as unit root test, cointegration test, and Granger causality test. And then we estimate the contribution of the investment in education to economic growth. We will give a conclusion and make some policy suggestions in Section 6.

\section{Literature Review}

In endogenous growth theory, education promotes innovation, knowledge of new technologies and products, thereby contributing to economic growth [7]. The existing literature has broadly discussed the relationship between educational investment and economic growth [8-12]. Schultz [13] mentioned that the investment of education and other aspects can also accelerate the economic growth 
in the Declaration of Human Capital Investment in 1960. Denison [14], the father of growth accounting, estimated the contribution rate of education to the national annual income growth (2.93\%) by residues analysis and found that education contributed $35 \%$ in United States, which pointed out that education makes great contributions to economic growth. William and Rebelo [15] found that there is a positive correlation between public education investment and economic growth. A group of scientists headed by Collins et al. [16] estimated the contribution of per capita education to the per capita growth among seven Asian countries, finding that the contribution of education investment to economic growth occupied $9.7 \%$ in South Korea from 1984 to 1994 . It can be concluded that education is an important factor influencing economic growth. Sylwester [17] also indicated that although education spending has a negative effect on economic growth in the short term, it plays a positive role in the long run. Ganegodage and Rambaldi [18] evaluated the contribution of investment on education to Sri Lanka's economic growth during the period 1959-2008, showing that the impact of education is assessed through a quality adjusted human capital stock measure and the returns to investment in education are positive but significantly lower than those found for other developing economies. Mercan and Sezer [19] found that a positive relationship between education expenses and economic growth was found in the Turkish economy over the period 1970-2012. A greater allocation of resources on educational investment could make the economy more dynamic.

There are different research methods in the literature on the impact of education on economic growth. With respect to the cointegration and Granger causality test, Omojimite [20] examined the hypothesis of economic growth led by improvements in the education sector, and found that public expenditures on education Granger cause economic growth. Afzal et al. [21] found the cointegration among economic growth and education, and the existence of the feedback causality between education and all levels of education with economic growth by using the cointegration and causality analysis from 1970-1971 to 2008-2009 in Pakistan. With regard to other methods, Zhang and Zhuang [22] investigated the impact of human capital composition on economic growth in China by using GMM method and suggested that tertiary education plays a more important role than primary and secondary education on economic growth. Tsamadias and Prontzas [23] revealed that education has a significantly positive effect on economic growth in Greece and this effect still exists when the time lag term is considered. Qadri and Waheed [24] used a macroeconomic model to reveal changes in educational spending that affect output by increasing productivity and multiplier acceleration principles. Yu et al. [12] implied that public education has a positive effect on promoting sustainable economic growth in the eastern region during 2005-2011 in China, while the gap in public education in the central and western regions is narrowing. Jalil and Idrees [25] used non-linear two stage least square instrumental models to evaluate the level and growth effects of education on the economic growth in Pakistan from 1960 to 2010, and showed there is a positive effect of different levels of education on economic growth. Woo et al. [26] also examined the impact of education and R\&D investment on regional economic growth by developing a log-linearized Cobb-Douglas regional production function in South Korea.

More investment in education can stimulate economic growth that leads to further education investment and then economic growth in turn [21]. The investment in higher education is the most. In terms of different levels of education, the labor force of different educational levels should have different effects on economic growth. Higher education leads to higher economic growth [21,27]. Lin [28] found that one additional year of education can increase real output by approximately $0.15 \%$ in Taiwan from 1965 to 2000. Lin [29] examined the effects of higher education curricula on the labor force and thus on economic growth in Taiwan, and found that higher education overall provided a positive and significant effect on Taiwan's economic development. Lv et al. [30] took into account the spatial spillover effects across 31 provinces over the period 1996-2010 in China and found that average schooling year has a more positive effect on economic growth than capital investment and labor force. However, Benos and Zotou [3] pointed out that there is substantial publication selection bias toward a positive impact of education on growth by surveying 57 studies. 
To the best of our knowledge, we can find most studies are based on macroscopic analysis using time series data while few studies emphasizes the structure and regional difference. Another point is the omission of the influence brought by other important variables (such as material capital investment) which increases the possibility of missing variable. What's more, using the classical model directly without data inspection appears frequently. Another defect is focusing too much on the influence of human capital on economic growth, which has done nothing to enhance the subject. At the same time, educational investment is not the only reason for economic growth, the other economic and noneconomic variables should be considered, such as fixed-asset investment and the amount of people in employment. In addition, there is less literature on the impact of Guangdong's economic investment on its sustainable economic growth in China, especially at the prefecture-level. As a result, this study employs panel data of each city in Guangdong province from 2000 to 2016 to reveal the relationship between educational investment and economic growth, and aims to answer what the relationship is between local finance educational investment and economic growth, what the differences are among the influences of regional educational investment in Guangdong province on economic growth and whether educational investment has a hysteresis effect on economic growth or not.

\section{Methodology and Data}

\subsection{Methodology}

In the Neo-economic growth theory, physical capital and human capital are the two critical capital inputs of economic output. Considering that education has the nature of the human capital, increased investment in education will promote the increase of capital. Educational investment, as a part of human capital, is one of the determinants of economic growth and has a significantly positive effect on economic development [31,32]. Therefore, we use educational investment as a proxy variable of human capital. Based on the Cobb-Doulas production function (the C-D function), the education production function is defined as

$$
Y_{i t}=A_{i t} K_{\mathrm{it}}^{\alpha} L_{\mathrm{it}}^{\beta} E_{i t}^{\delta}
$$

where $Y_{i t}$, the output level, is measured by real gross domestic product. $i$ denotes respective prefecture-level city. $t$ denotes the time period, $A$ is the technological level. $K$, the physical capital input, is measured by the real fixed-asset investment. $L$, the labor force, is measured by the amount of people in employment. $E$, the human capital input, is a measure of real educational investment. $\alpha$ represents the elasticity of output relative to physical capital input. $\beta$ represents the elasticity of output relative to labor force input. $\delta$ represents the elasticity of output relative to human capital input. That is to say, $\alpha$ is the contribution ratio that the real physical capital investment devotes to the economic growth, and $\beta$ is the contribution ratio that the amount of people in employment at the end of the year devotes to the economic growth. At last, $\delta$ is the contribution ratio which is devoted to economic growth.

In our study, the collected data is panel data which combine the nature of cross-section data and time series data, so the econometric model which is established on panel data can analyze the contribution of educational investment to economic growth more effectively. At the same time, the panel data model cannot avoid the heteroscedasticity and stability problems. Therefore, we need to conduct a various of tests on the panel data model based on our research information, and ultimately get the theoretical model we need. The logarithmic transformation to the education production function not only can mitigate the heteroscedasticity problem, but also can reduce steps to unit roots test.

The general form of panel data model is specified as

$$
\mathrm{y}_{i t}=\alpha_{i}+x_{i t} \beta_{i}+\mu_{i t}
$$

where $x_{i t}$ is the vector of $1 \times K, \beta_{i}$ is the vector of $K \times 1, K$ is the number of explanatory variable, $\mu_{i t}$ is the stochastic error term. Finally, the panel data model has three general forms as below. 
If $\alpha_{i}=\alpha_{j}, \beta_{i}=\beta_{j}$, the mixed model is defined as

$$
y_{i t}=\alpha+x_{i t} \beta+\mu_{i t}
$$

If $\alpha_{i} \neq \alpha_{j}, \beta_{i}=\beta_{j}$, the variable intercept model is defined as

$$
\mathrm{y}_{i t}=\alpha_{i}+x_{i t} \beta+\mu_{i t}
$$

If $\alpha_{i} \neq \alpha_{j}, \beta_{i} \neq \beta_{j}$, the variable coefficient model is defined as

$$
y_{i t}=\alpha_{i}+x_{i t} \beta_{i}+\mu_{i t}
$$

The F-statistic of Equations (3) and (4) is, respectively,

$$
\begin{aligned}
& F_{1}=\frac{\left(S_{1}-S_{3}\right) /[(N-1)(k+1)]}{S_{3} /(N T-N(k+1))} \sim F[(N-1)(k+1), N(T-k-1)] \\
& F_{2}=\frac{\left(S_{2}-S_{3}\right) /[(N-1)(k+1)]}{S_{3} /(N T-N(k+1))} \sim F[(N-1)(k+1), N(T-k-1)]
\end{aligned}
$$

where $S_{1}$ is the residual sum of squares of Equation (3), $S_{2}$ is the residual sum of squares of Equation (4) and $S_{3}$ is the residual sum of squares of Equation (5). Both Equations (3) and (4) can be involved with two cases: the fixed effect and the random effect. And then we can determine what kind of effect we need by means of the Hausman test. Based on our sample data, statistical results of the test can be shown as follows by Table 1 . Given the significance level of $1 \%$, the $p$-value is 0 , thus we can reject the null and choose the fixed effect model. Finally, the fixed effect model in the form of logarithmic can be defined as Equation (8). $X$ denotes series of control variables, including net exports (NE), technical import (IT), energy consumption (EC), industry structure (IS), R\&D (RD), and migration (MG).

$$
\ln \mathrm{GDP}_{\mathrm{it}}=\alpha_{i}+\beta \ln K_{i t}+\gamma \ln E_{i t}+\delta \ln L_{i t}+\theta X_{i t}+u_{i t}
$$

Table 1. The results of Hausman test.

\begin{tabular}{cccccccccc}
\hline & & \multicolumn{9}{c}{ Hausman Test } & Conclusion \\
\cline { 3 - 8 }$S_{1}$ & $S_{2}$ & $S_{3}$ & F1-Statistic & $\begin{array}{c}\text { Critical } \\
\text { Values } \\
(\alpha=0.05)\end{array}$ & F2-Statistic $\begin{array}{c}\text { Critical } \\
\text { Values } \\
(\alpha=0.05)\end{array}$ & $\begin{array}{c}\text { Chi-Sq. } \\
\text { Statistic }\end{array}$ & Prob. & $\begin{array}{c}\text { use the variable } \\
\text { coefficient model } \\
\text { with fixed effect }\end{array}$ \\
\hline 21.4 & 2.34 & 0.45 & 91.5631 & 1.34 & 0.0031 & 1.38 & 26.47 & 0.0000 & \\
\hline
\end{tabular}

\subsection{Data}

Our data selected in the study are from the panel data of 21 prefecture-level cities in Guangdong of China from 2000 to 2016. The data are processed according to the Guangdong province yearbooks (2001-2017), the yearbooks of each city (2001-2017) and the local government websites [33]. Few missing data are obtained by interpolation. Based on panel data model, the variables adopted to analyze the relationship between educational investment and economic growth are as follows: the real gross domestic product (GDP), the real physical capital stock, the real investment in education and labor. Educational investment refers to the recurring expenses for various educational undertakings in the state's fiscal expenditure, that is, the public education expenses paid by the government [12]. In China, various educational investments include the investment in educational administration, preschool education, primary education, junior high school education, general high school education, general higher education, primary vocational education, secondary vocational education, technical school education, vocational high school education, higher vocational education, foreign students' education, special education and service of educational institutions and so on. The expenditure on education 
consists of two parts: personnel expenditure and public expenditure. Personnel expenditure mainly includes wages, subsidies, and grants, etc. Public expenditure is mainly used for official services, equipment purchases, and repairs. Capital stock is calculated by using the perpetual inventory method [34]. The best measure of labor should be the number of years of formal education per person in the labor force [28,29]. However, limited by the data, labor is measured by the amount of people in employment at the end of the year in each city [21]. We choose the amount of foreign investment actually used in the year as an indicator of technical import. The electricity consumption of each city is used as a substitute for energy consumption [35]. The proportion of the added value of the secondary industry to GDP is used as an indicator to measure the industrial structure. Considering the mobility of human capital, we also control the variable of migration that people who live in the border of Guangdong go to neighbor provinces to consume and work. Limited by the data, we use the number of people migrating outside the province as a proxy variable. All nominal variables are deflated to real variables by using a price index, so as to mitigate the impact of price changes of each city. Table 2 presents the descriptive statistics for the data.

Table 2. The descriptive statistics of the sample data.

\begin{tabular}{cccc}
\hline Variable & Obs. & Mean & Std. Dev. \\
\hline GDP & 357 & 1602.90 & 2175.23 \\
L & 357 & 255.55 & 171.03 \\
K & 357 & 2703.77 & 3410.85 \\
E & 357 & 32.89 & 37.61 \\
NE & 357 & 267.53 & 550.18 \\
IT & 357 & 53.67 & 65.72 \\
EC & 357 & 129.16 & 190.62 \\
IS & 357 & 47.11 & 8.63 \\
RD & 357 & 5.66 & 17.66 \\
MG & 357 & 7749.49 & 7302.76 \\
\hline
\end{tabular}

In order to analyze and investigate the linkage between educational investment and economic growth among different regions of Guangdong province, we further divide the panel data of Guangdong province into four parts in accordance with its economic regions [36]: Pearl River Delta, Eastern region, Western region, and Mountainous region.

\section{Empirical Results}

\subsection{Unit Root Test}

In order to obtain more stable results and determine whether there is a long run and stable relationship between educational investment and economic growth, we conduct stationarity test on non-stationary variables in the macro-economy, including the gross domestic product, the amount of people in employment, physical capital, and the investment in education. The following methods have been applied in the study, including Levin, Lin \& Chu test (LLC), ImPesaran and Shin W-stat test (IPS), ADF-Fisher Chi-square test (Fisher-ADF), and PP-Fisher Chi-square test (PP-ADF). The results are as follows in Table 3.

Table 3. Unit Root Test results.

\begin{tabular}{llllll}
\hline Economic Region & Variable & LLC Test & IPS Test & F-ADF Test & F-PP Test \\
\hline \multirow{5}{*}{ Total Province } & $\operatorname{lnGDP}$ & 0.9651 & 1.0000 & 0.9985 & 0.9971 \\
& DlnGDP & $0.0000^{* * *}$ & $0.0025^{* * *}$ & $0.0026^{* * *}$ & $0.0004^{* * *}$ \\
& $\operatorname{lnK}$ & 0.9752 & 1.0000 & 1.0000 & 0.9861 \\
& DlnK & $0.0000^{* * *}$ & $0.0001^{* * *}$ & $0.0001^{* * *}$ & $0.0000^{* * *}$ \\
& $\operatorname{lnL}$ & 0.6961 & 0.7643 & 0.6347 & 0.8519 \\
& DlnL & $0.0000^{* * *}$ & $0.0001^{* * *}$ & $0.0000^{* * *}$ & $0.0000^{* * *}$ \\
\hline
\end{tabular}


Table 3. Cont.

\begin{tabular}{|c|c|c|c|c|c|}
\hline Economic Region & Variable & LLC Test & IPS Test & F-ADF Test & F-PP Test \\
\hline & $\ln E$ & $0.0001^{* * * *}$ & 0.8761 & 0.9351 & 0.2461 \\
\hline & $D \ln E$ & $0.0000^{* * *}$ & $0.0001^{* * *}$ & $0.0000^{* * *}$ & $0.0001^{* * *}$ \\
\hline \multirow{8}{*}{ Pearl River Delta } & $\operatorname{lnGDP}$ & $0.0018^{* * *}$ & 0.6372 & 0.6104 & 0.3614 \\
\hline & DlnGDP & $0.0006^{* * *}$ & 0.1643 & 0.1103 & 0.1463 \\
\hline & $\ln K$ & 0.7658 & 1.0000 & 0.9647 & 0.5431 \\
\hline & DlnK & $0.0000^{* * *}$ & $0.0003^{* * *}$ & $0.0006^{* * * *}$ & $0.0008^{* * *}$ \\
\hline & $\ln \mathrm{L}$ & 0.1953 & 0.9044 & 0.8867 & 0.5797 \\
\hline & $\mathrm{DlnL}$ & $0.0000^{* * *}$ & $0.0000^{* * *}$ & $0.0000^{* * *}$ & $0.0007^{* * *}$ \\
\hline & $\ln E$ & 0.3841 & 0.9987 & 0.9989 & 0.8034 \\
\hline & $D \ln E$ & $0.0001^{* * *}$ & $0.0001^{* * *}$ & $0.0000^{* * *}$ & $0.0001^{* * *}$ \\
\hline \multirow{8}{*}{ Eastern Region } & $\operatorname{lnGDP}$ & 1.0000 & 1.0000 & 1.0000 & 1.0000 \\
\hline & DlnGDP & $0.0001^{* * *}$ & $0.0316^{* *}$ & $0.0201^{* *}$ & $0.0000^{* * *}$ \\
\hline & $\ln K$ & 0.9994 & 1.0000 & 0.9933 & 0.9967 \\
\hline & $\mathrm{DlnK}$ & $0.0000^{* * *}$ & $0.0596^{*}$ & $0.0614^{*}$ & $0.0034^{* * *}$ \\
\hline & $\ln \mathrm{L}$ & 0.9934 & 0.9670 & 0.3301 & 0.6913 \\
\hline & $D \ln L$ & $0.0057^{* * *}$ & 0.1643 & $0.0631^{*}$ & $0.0634^{*}$ \\
\hline & $\ln \mathrm{E}$ & $0.0601^{*}$ & 0.6920 & 0.5967 & 0.3946 \\
\hline & $D \ln E$ & $0.0000^{* * *}$ & $0.0001^{* * *}$ & $0.0000^{* * *}$ & $0.0000^{* * *}$ \\
\hline \multirow{8}{*}{ Western Region } & $\operatorname{lnGDP}$ & 0.9997 & 0.9937 & 1.0000 & 1.0000 \\
\hline & DlnGDP & $0.0083^{* * *}$ & 0.2063 & 0.3461 & 0.6941 \\
\hline & $\ln K$ & 0.9987 & 1.0000 & 0.9745 & 1.0000 \\
\hline & DlnK & $0.0000^{* * *}$ & $0.0248^{* *}$ & $0.0159^{* *}$ & 0.1671 \\
\hline & $\ln L$ & 0.3025 & 0.3461 & 0.4016 & 0.1346 \\
\hline & $\mathrm{D} \ln \mathrm{L}$ & $0.0078^{* * *}$ & $0.0369^{* *}$ & $0.0235^{* *}$ & $0.0304^{* *}$ \\
\hline & $\ln E$ & $0.0009^{* * *}$ & $0.0854^{*}$ & $0.0642 *$ & 0.1643 \\
\hline & $D \ln E$ & $0.0001^{* * *}$ & $0.0000^{* * *}$ & $0.0000^{* * *}$ & $0.0000^{* * *}$ \\
\hline \multirow{8}{*}{ Mountainous Region } & $\operatorname{lnGDP}$ & 0.8649 & 0.9962 & 0.9889 & 1.0000 \\
\hline & DlnGDP & $0.0006^{* * *}$ & $0.0126^{* *}$ & $0.0174^{* *}$ & 0.1340 \\
\hline & $\ln K$ & $0.0198^{* *}$ & 0.7956 & 0.8341 & 0.8031 \\
\hline & $\mathrm{D} \operatorname{lnK}$ & $0.0000^{* * *}$ & $0.0175^{* *}$ & $0.0167^{* *}$ & $0.0034^{* * *}$ \\
\hline & $\ln L$ & $0.0137^{* *}$ & 0.1862 & 0.2461 & 0.3015 \\
\hline & $D \ln L$ & $0.0000^{* * *}$ & $0.0031^{* * *}$ & $0.0076^{* * *}$ & $0.0001^{* * *}$ \\
\hline & $\ln \mathrm{E}$ & $0.0203^{* *}$ & 0.3544 & 0.8140 & 0.1203 \\
\hline & $D \ln E$ & $0.0001^{* * *}$ & $0.0004^{* * *}$ & $0.0007^{* * *}$ & $0.0003^{* * *}$ \\
\hline
\end{tabular}

Notes: ${ }^{* * *}, * *, *$ respectively means that we reject the null hypothesis under the significance level of $1 \%, 5 \%$ and $10 \%$, and the values are $p$-values. The null hypothesis is that unit root exists.

According to LLC, IPS, Fisher-ADF and PP-ADF test results in Table 3, all variables including $\ln G D P_{i t}, \ln K_{i t}, \ln E_{i t}$, and $\ln L_{i t}$ are non-stationary series. Given the significance level of $5 \%$, the probability of all variables is upper than $5 \%$. Thus we cannot reject the null hypothesis that unit root exists. However, when testing each variable series for unit root in first difference, we find that $D \ln G D P_{i t}, D \ln K_{i t}, D \ln E_{i t}$, and $D \ln L_{i t}$ are stationary series. At the significance of $5 \%$, the probability of all variables is lower than $5 \%$. Thus we can reject the null hypothesis. Finally, we can conclude that $\ln G D P_{i t}, \ln K_{i t}, \ln E_{i t}$, and $\ln L_{i t}$ are non-stationary series of first-order integration. At this point, to avert the spurious regression problem, we can avoid it by using traditional panel estimation methods. Therefore, we can further conduct cointegration tests to examine the long run equilibrium relationship between educational investment and sustainable economic growth.

\subsection{Panel Cointegration Result}

Cointegration analysis of panel data began in the year of 1995. Pedroni [37] and Kao [38] studied the spurious regressions and the cointegration test. The cointegration test is based on the fact that gross domestic product, the amount of people in employment, physical capital, and educational 
investment are usually non-stationary in the real economy. Although we can use these variables in the form of difference to make them more stable, this will lead to the result that we lose the gross long run information which is necessary to analyze some problems. Consequently, on the basis of the stationary results gained in the unit root test, we can conduct cointegration tests to make a further study. We mainly adopt the Pedroni test, including seven statistics, such as Panel V, Panel Rho, Panel PP, Panel ADF, Group Rho, Group PP, and Group ADF. These results are shown in Table 4.

Table 4. Panel Cointegration Test.

\begin{tabular}{cccccc}
\hline Statistic & Total Province & $\begin{array}{c}\text { Pearl } \\
\text { River Delta }\end{array}$ & $\begin{array}{c}\text { Eastern } \\
\text { Region }\end{array}$ & $\begin{array}{c}\text { Western } \\
\text { Region }\end{array}$ & $\begin{array}{c}\text { Mountainous } \\
\text { Region }\end{array}$ \\
\hline Panel V & $0.0823^{*}$ & $0.0784^{*}$ & 0.8520 & $0.0001^{* * *}$ & 0.9001 \\
Panel Rho & $0.0912^{*}$ & 0.3025 & $0.0298^{* *}$ & 0.6284 & 0.2130 \\
Panel PP & $0.0802^{*}$ & 0.1456 & $0.0005^{* * *}$ & 0.3654 & $0.0002^{* * *}$ \\
Panel ADF & $0.0203^{* *}$ & $0.0365^{* *}$ & $0.0001^{* * *}$ & 0.1152 & $0.0007^{* * *}$ \\
Group Rho & $0.0895^{*}$ & 0.7865 & 0.6592 & 0.7438 & 0.6823 \\
Group PP & $0.0006^{* * *}$ & 0.3965 & $0.0214^{* *}$ & 0.7561 & $0.0021^{* * *}$ \\
Group ADF & $0.0067^{* * *}$ & $0.0087^{* * *}$ & $0.0036^{* * *}$ & $0.0396^{* *}$ & $0.0285^{* *}$ \\
\hline
\end{tabular}

Notes: ${ }^{* * *}, * * * *$ respectively means that we reject the null hypothesis for $1 \%, 5 \%$ and $10 \%$ significance levels, and the values are $p$-values. The null hypothesis is that cointegration relationship does not exist.

The empirical results (see Table 4) show that all of the statistics of Guangdong province have passed the test at the significance level of $1 \%, 5 \%$, or $10 \%$. Due to the better small sample properties of panel ADF and group ADF compared with other statistics in the Pedroni test, Panel ADF and Group ADF of the four big economic regions have passed the test at the significance level of $1 \%, 5 \%$, or $10 \%$. Therefore, we can make a conclusion that a long run and stable cointegration relationship exists between educational investment and economic growth in Guangdong province as well as its four big economic regions. Omojimite [20] also revealed that there is cointegration between public expenditures on education and economic growth.

\subsection{Granger Causality Test}

The cointegration relationship above indicates that there is a long-run equilibrium relationship between educational investment and sustainable economic growth. However, education and economic growth is not a one-way process, it is a two-way process $[39,40]$. Thus we still need to test whether there is a causality in the equilibrium relationship. In this regard, we use Granger causality test to study further, then tests the causality between educational investment and economic growth by choosing different lags. The test results are shown in Table 5.

Table 5. Education and GDP Granger causality test.

\begin{tabular}{lllllll}
\hline \multirow{2}{*}{ Granger Causality } & \multicolumn{7}{c}{ Lags } \\
\cline { 2 - 7 } & $\mathbf{1}$ & $\mathbf{2}$ & $\mathbf{3}$ & $\mathbf{4}$ & $\mathbf{5}$ & $\mathbf{6}$ \\
\hline GDP does not Granger Cause E & $0.0002^{* * *}$ & $0.0004^{* * *}$ & $0.0009^{* * *}$ & $0.0312^{* *}$ & $0.0402^{* *}$ & 0.1101 \\
E does not Granger Cause GDP & $0.0041^{* * *}$ & $0.0073^{* * *}$ & $0.0090^{* * *}$ & $0.0276^{* *}$ & $0.0382^{* *}$ & $0.0361^{* *}$ \\
\hline
\end{tabular}

Notes: Lag Intervals for Endogenous is determined by the SC and AIC judgment criterion; The values are $p$-values. $* * *, * *, *$ indicates respectively the significance level of $1 \%, 5 \%$ and $10 \%$.

The result of Table 5 shows that, in the short term, educational investment is the Granger cause of economic growth. Meanwhile, economic growth is also the Granger cause of the educational investment. However, in the long run, educational investment is the Granger cause of economic growth, but economic growth is not the Granger cause of educational investment. That is to say, educational investment and economic growth have two-way causality in the short term, the growth of educational investment will promote the development of economy, and the growth of economy will 
promote the increase of educational investment further. But in the long-run, educational investment and economic growth have unidirectional causality, educational investment is the important source of economic growth. Afzal et al. [21] also noted that economic growth can be further accelerated with more investment in education, that in turn, leads to further education and hence economic growth.

\subsection{Estimating the Contribution of the Investment in Education to Economic Growth}

After the above tests, we analyze the relationship between the investment in education and economic growth of 21 cities of Guangdong province from 2000 to 2016, and use panel data model for the above education production function. Finally, we obtain the regression analysis results in Table 6 .

Table 6. The results of estimation by fixed effect panel data model in Guangdong province.

\begin{tabular}{|c|c|c|c|c|c|}
\hline Variables & Total Province & $\begin{array}{c}\text { Pearl } \\
\text { River Delta }\end{array}$ & Eastern Region & $\begin{array}{l}\text { Western } \\
\text { Region }\end{array}$ & $\begin{array}{c}\text { Mountainous } \\
\text { Region }\end{array}$ \\
\hline \multirow[t]{2}{*}{$\ln E$} & $0.1401^{* *}$ & $0.2324^{* * *}$ & $0.0808^{* *}$ & $0.1328^{*}$ & $0.0364^{*}$ \\
\hline & $(0.018)$ & $(0.001)$ & $(0.042)$ & $(0.062)$ & $(0.077)$ \\
\hline \multirow[t]{2}{*}{$\ln L$} & $0.2096^{* * *}$ & $0.1563^{* * *}$ & -0.2177 & -0.1999 & -0.1002 \\
\hline & $(0.000)$ & $(0.000)$ & $(0.121)$ & $(0.366)$ & $(0.476)$ \\
\hline \multirow[t]{2}{*}{$\ln K$} & $0.2050^{* * *}$ & 0.0224 & $0.3033^{* * *}$ & 0.1000 & $0.1695^{* *}$ \\
\hline & $(0.000)$ & $(0.401)$ & $(0.000)$ & $(0.149)$ & $(0.029)$ \\
\hline \multirow[t]{2}{*}{$\ln R D$} & 0.0097 & -0.0018 & $0.0321^{* *}$ & -0.0192 & $0.0270^{*}$ \\
\hline & $(0.192)$ & $(0.878)$ & $(0.022)$ & $(0.466)$ & $(0.052)$ \\
\hline \multirow[t]{2}{*}{$\operatorname{lnIT}$} & -0.0100 & $0.0600^{* * *}$ & $0.0691^{* * *}$ & -0.0060 & -0.0381 \\
\hline & $(0.379)$ & $(0.000)$ & $(0.001)$ & $(0.612)$ & $(0.194)$ \\
\hline \multirow[t]{2}{*}{$\operatorname{lnEC}$} & 0.0181 & -0.0072 & $0.0590^{* *}$ & $0.0658^{*}$ & $0.1470^{* * *}$ \\
\hline & $(0.377)$ & $(0.719)$ & $(0.019)$ & $(0.074)$ & $(0.000)$ \\
\hline \multirow[t]{2}{*}{ IS } & $0.0086^{* * *}$ & $0.0070^{* * *}$ & $0.0047^{*}$ & 0.0032 & $0.0138^{* * *}$ \\
\hline & $(0.000)$ & $(0.000)$ & $(0.092)$ & $(0.412)$ & $(0.000)$ \\
\hline \multirow[t]{2}{*}{ NE } & $0.0001^{* * *}$ & $0.0000^{* *}$ & $0.0003^{* *}$ & -0.0000 & $0.0012^{*}$ \\
\hline & $(0.000)$ & $(0.028)$ & $(0.028)$ & $(0.973)$ & $(0.059)$ \\
\hline \multirow[t]{2}{*}{$\operatorname{lnMG}$} & $0.0174^{*}$ & 0.0107 & 0.0103 & 0.0148 & 0.0101 \\
\hline & $(0.071)$ & $(0.420)$ & $(0.560)$ & $(0.346)$ & $(0.697)$ \\
\hline \multirow[t]{2}{*}{ Constant } & $10.2640^{* * *}$ & $15.5114^{* * *}$ & $10.2617^{* * *}$ & $14.1050^{* * *}$ & $10.3882^{* * *}$ \\
\hline & $(0.000)$ & $(0.000)$ & $(0.000)$ & $(0.000)$ & $(0.000)$ \\
\hline Observations & 357 & 153 & 68 & 51 & 85 \\
\hline Adj. $\mathrm{R}^{2}$ & 0.9957 & 0.9982 & 0.9980 & 0.9991 & 0.9948 \\
\hline
\end{tabular}

Notes: The values in the parentheses are $p$-values of the coefficient. ${ }^{* * *}, * *, *$ indicates respectively the significance level of $1 \%, 5 \%$ and $10 \%$. All regressions contain city and year fixed effects. These are based on robust standard errors that have been adjusted for clustering by city-year.

The result from Table 6 shows that the educational investment in the 21 cities of Guangdong province plays a positive role in promoting economic growth. At the significance level of $5 \%, \ln E$ of the whole province averagely increase by $1 \%$, lnGDP approximately increase by $0.14 \%$. But educational investment has a heterogeneous effect on economic growth because of the differences of the educational investment and policy in each economic region. The contribution of educational investment to economic growth in the Pearl River Delta, the Eastern region, the Western region, and Mountainous region are $0.2324,0.0808,0.1328,0.0364$, respectively. The contribution of the educational investment to economic growth in the Pearl River Delta is much higher than the other three regions. These results clearly prove that there is a long run equilibrium relationship between educational investment and economic growth. More developed regions benefit more from higher education, while less developed regions rely more on primary and secondary education [22]. As a result, the development of education promotes economic growth, and economic growth contributes to the development of education in turn. 


\subsection{The Hysteresis Effect Analysis about the Educational Investment on Economic Growth}

As mentioned above, there is a long run equilibrium relationship between educational investment and economic growth. Therefore, the question is whether the educational investment promotes the growth of economy immediately in the short term, or makes a difference on economic growth in few years? In order to resolve these doubts, we will analyze whether the educational investment has an obvious hysteresis effect on economic growth.

Appendix Tables A1-A5 show that when the lag is one year, in terms of the whole province, the contribution of education to economic growth in that year is 0.1371 . However, educational investment of last year also makes a certain contribution to economic growth. When the lag phase is two years, in terms of the whole province, the contribution of education to economic growth of that year is 0.1365, and the contributions of the Pearl River Delta, Eastern region, Western region, and Mountainous region are $0.2034,0.0725,0.0835,0.0306$, respectively. The contributions of education to economic growth of last two years' educational investment on the whole province and the four major economic areas are 0.0122, 0.0493, 0.0036, 0.0299, 0.0063, respectively. But when the lag phase is three years, the contributions of the last two years' educational investment on the whole province and the four major economic areas are $0.0108,0.0117,0.0042,0.0007,0.0013$, respectively. Obviously, the contribution rate of the last two years is almost higher than the contribution rate of the last three years. Also, these models' results do not pass the tests when the lag phase is three years. On the whole, when educational investment lags two years, the contribution rate of educational investment to economic growth reaches the maximum, the educational investment obviously has a hysteresis effect on economic growth. This denominates that the effect of the investment in education is long-term continual, which is composed of the following reasons. On the one hand, the training of specialized personnel often takes much time and investment on education without any outputs during this period. On the other hand, the outcomes of investment on education, performed as the educated intellectual, quality, and labor skills, can play a critical role for the educated for a long time, even a lifetime.

\section{Conclusions and Recommendations}

This study uses the individual fixed effect variable intercept model to make an empirical analysis on the relationship between educational investment and the growth of economy of different cities in Guangdong province. It mainly discusses the short-term and long-run effects of the contribution of educational investment to the growth of economy in view of the whole province and the four big economic regions. First of all, there is a positive correlation between educational investment and the growth of economy in each city. From 2000 to 2016, educational investment plays an important role in promoting economic growth. Educational investment increased by $1 \%$ will lead to the increase of gross domestic product by $0.14 \%$, on average. As a result, with the aim of boosting the economy, the government of each city should increase educational investment and improve the service efficiency in order to develop more talents and increase the contribution rate of educational investment to gross domestic product.

Secondly, educational investment of each city in Guangdong province has a lag influence on its economic growth. According to the results of the research, we find that educational investment has a two-year lag effect on the economic growth. In other words, with the increase of lag phase, the educational investment will strengthen its promotion effect on economic growth and reaches its maximum level of 0.1365 in the second year. It shows that the influence of educational investment to economic growth is a long run process rather than an immediate one. Therefore, the government of each city in Guangdong province should continuously increase the educational investment, improve the education system constantly, and reform the education system step by step if they want to develop the local economy by means of education.

However, education is not the only factor to boost economy. The amount of people in employment, the fixed-assets investment and all kinds of hardware and software facilities also have a significant impact on the growth of economy in each city. Meanwhile, these factors can affect the efficiency of the 
educational investment. The differences among the cities show that Guangzhou, Dongguan, Foshan, and Shenzhen are ahead all the time regardless of the lag length, while Qingyuan, Yunfu, Heyuan, and Shanwei always fall behind. It can be drawn from this that the level of educational investment and the efficiency of education can reach to a higher point with better facilities, better education foundation, and better supporting facilities. Thus, the government of each city should take these measures, such as improving facilities and developing the education foundation.

Finally, the effect of educational investment varies among cities in Guangdong province, especially the four economic regions. In terms of the four economic regions, we can rank them as follows (from high level to low level) according to the contribution rate of educational investment to the economic growth: Pearl River Delta, the Western region, the Mountainous region, the Eastern region. The contribution of educational investment to the growth of economy in the Mountainous region is nearly the same as that of the East region. The contribution rate in the Pearl River Delta is much higher than the other regions. It shows that the development of education promotes the growth of the economy, and the growth of the economy has a positive effect on the development of education in turn. Therefore, Guangdong province should adopt the policy, inclining towards relatively less developed areas to promote the growth of economy and increase the educational investment at the same time by implementing preferential policies. What's more, each city should continually improve the education institutions to coordinate the relationship between educational investment and economic growth in order to promote the development of economy by means of education.

Thus, according to our research, some political implications can be drawn. Firstly, the strategy of prospering the nation with science and education should be thoroughly carried out, and the government should develop an appropriate strategy to allocate resources on education to improve its returns to the economy [18]. What's more, the government ought to raise the proportion of the educational investment in the financial expenditure to ensure the coordinated and sustainable development of educational investment and the economic growth. Secondly, the financial condition in the less developed regions should be fully considered, the intergovernmental transfer payment system should be improved actively to dwindle the differences of educational investment and economic development among different regions. Thirdly, the government should make sure that the educational investment is made full use of. At the same time, education institutions should be improved actively and the efficiency of educational investment should be raised in each city in Guangdong province. It is also recommended that the nexus between education and economic growth with inclusion of other variables other than physical capital and labor force should further be tested and generalized [21], which will be of interest to analyze in future studies.

Author Contributions: Liping Liao contributed to the acquisition of data, analysis and interpretation of the data and drafting the article; Minzhe Du, Bing Wang and Yanni Yu made substantial contributions to the concept and design of the article. Both of the authors helped to revised the manuscript and approved its final publication.

Acknowledgments: The study is supported by the Key Project of Philosophy and Social Sciences Research of Ministry of Education of China (17JZD013), the National Natural Science Foundation of China (71473105, 71711540308,71603102).

Conflicts of Interest: The authors declare no conflict of interest.

\section{Appendix A}

Table A1. The results of the hysteresis effect analysis (Total Province).

\begin{tabular}{cccc}
\hline Variables & $\mathbf{( 1 )}$ & $\mathbf{( 2 )}$ & $\mathbf{( 3 )}$ \\
\hline $\ln \mathrm{E}$ & $0.1371^{* *}$ & $0.1365^{* *}$ & $0.1344^{* *}$ \\
& $(0.041)$ & $(0.044)$ & $(0.033)$ \\
L. $\ln \mathrm{E}$ & $0.0121^{* *}$ & $0.0156^{* *}$ & $0.0182^{* *}$ \\
& $(0.014)$ & $(0.025)$ & $(0.040)$ \\
L2. $\ln \mathrm{E}$ & & $0.0122^{*}$ & $0.0108^{*}$ \\
\hline
\end{tabular}


Table A1. Cont.

\begin{tabular}{|c|c|c|c|}
\hline Variables & (1) & (2) & (3) \\
\hline & & $(0.080)$ & $(0.071)$ \\
\hline L3. $\ln E$ & & & $\begin{array}{l}0.0066 \\
(0.176)\end{array}$ \\
\hline $\ln L$ & $\begin{array}{c}0.1903^{* * *} \\
(0.000)\end{array}$ & $\begin{array}{c}0.1783^{* * *} \\
(0.000)\end{array}$ & $\begin{array}{c}0.1504^{* * *} \\
(0.001)\end{array}$ \\
\hline $\ln K$ & $\begin{array}{c}0.2297^{* * *} \\
(0.000)\end{array}$ & $\begin{array}{c}0.2534^{* * *} \\
(0.000)\end{array}$ & $\begin{array}{c}0.2784^{* * * *} \\
(0.000)\end{array}$ \\
\hline $\ln R D$ & $\begin{array}{l}0.0083 \\
(0.298)\end{array}$ & $\begin{array}{l}0.0087 \\
(0.300)\end{array}$ & $\begin{array}{l}0.0097 \\
(0.301)\end{array}$ \\
\hline $\ln I T$ & $\begin{array}{c}-0.0146 \\
(0.203)\end{array}$ & $\begin{array}{l}0.0213^{*} \\
(0.072)\end{array}$ & $\begin{array}{l}0.0239^{*} \\
(0.052)\end{array}$ \\
\hline $\operatorname{lnEC}$ & $\begin{array}{l}0.0158 \\
(0.468)\end{array}$ & $\begin{array}{l}0.0197 \\
(0.423)\end{array}$ & $\begin{array}{l}0.0162 \\
(0.514)\end{array}$ \\
\hline IS & $\begin{array}{c}0.0073^{* * *} \\
(0.000)\end{array}$ & $\begin{array}{c}0.0062^{* * *} \\
(0.000)\end{array}$ & $\begin{array}{c}0.0049^{* * *} \\
(0.000)\end{array}$ \\
\hline NE & $\begin{array}{c}0.0001^{* * *} \\
(0.000)\end{array}$ & $\begin{array}{c}0.0001^{* * *} \\
(0.000)\end{array}$ & $\begin{array}{c}0.0001^{* * *} \\
(0.000)\end{array}$ \\
\hline $\ln M G$ & $\begin{array}{l}0.0116 \\
(0.225)\end{array}$ & $\begin{array}{l}0.0048 \\
(0.598)\end{array}$ & $\begin{array}{l}0.0012 \\
(0.892)\end{array}$ \\
\hline Constant & $\begin{array}{c}10.0985^{* * *} \\
(0.000)\end{array}$ & $\begin{array}{c}9.8651^{* * *} \\
(0.000)\end{array}$ & $\begin{array}{c}9.8630^{* * * *} \\
(0.000)\end{array}$ \\
\hline Observations & 336 & 315 & 294 \\
\hline Adj. $\mathrm{R}^{2}$ & 0.9960 & 0.9962 & 0.9965 \\
\hline
\end{tabular}

Notes: The values in the parentheses are $p$-values of the coefficient. ${ }^{* * *},{ }^{* *}, *$ indicates respectively the significance level of $1 \%, 5 \%$ and $10 \%$.

Table A2. The results of the hysteresis effect analysis (Pearl River Delta).

\begin{tabular}{|c|c|c|c|}
\hline Variables & (1) & (2) & (3) \\
\hline $\ln E$ & $\begin{array}{c}0.2063^{* * *} \\
(0.001)\end{array}$ & $\begin{array}{c}0.2034^{* * *} \\
(0.000)\end{array}$ & $\begin{array}{c}0.2001^{* * *} \\
(0.006)\end{array}$ \\
\hline L. $\ln E$ & $\begin{array}{c}0.0473^{* * *} \\
(0.009)\end{array}$ & $\begin{array}{c}0.0163^{* *} \\
(0.037)\end{array}$ & $\begin{array}{c}0.0010^{* *} \\
(0.046)\end{array}$ \\
\hline L2. $\ln E$ & & $\begin{array}{c}0.0493^{* *} \\
(0.016)\end{array}$ & $\begin{array}{l}0.0117^{*} \\
(0.065)\end{array}$ \\
\hline L3. $\ln E$ & & & $\begin{array}{c}0.0532^{*} \\
(0.100)\end{array}$ \\
\hline $\ln L$ & $\begin{array}{c}0.1581^{* * *} \\
(0.002)\end{array}$ & $\begin{array}{c}0.1539^{* * *} \\
(0.010)\end{array}$ & $\begin{array}{c}0.1736^{* *} \\
(0.028)\end{array}$ \\
\hline $\ln K$ & $\begin{array}{l}0.0246 \\
(0.393)\end{array}$ & $\begin{array}{l}0.0362 \\
(0.267)\end{array}$ & $\begin{array}{l}0.0270 \\
(0.415)\end{array}$ \\
\hline $\ln R D$ & $\begin{array}{c}-0.0027 \\
(0.828)\end{array}$ & $\begin{array}{l}0.0055 \\
(0.633)\end{array}$ & $\begin{array}{l}0.0145 \\
(0.259)\end{array}$ \\
\hline $\operatorname{lnIT}$ & $\begin{array}{c}0.0535^{* * *} \\
(0.001)\end{array}$ & $\begin{array}{c}0.0556^{* * *} \\
(0.002)\end{array}$ & $\begin{array}{c}0.0414^{* *} \\
(0.014)\end{array}$ \\
\hline $\operatorname{lnEC}$ & $\begin{array}{c}-0.0104 \\
(0.675)\end{array}$ & $\begin{array}{c}-0.0082 \\
(0.853)\end{array}$ & $\begin{array}{l}0.0523 \\
(0.363)\end{array}$ \\
\hline IS & $\begin{array}{c}0.0067^{* * * *} \\
(0.000)\end{array}$ & $\begin{array}{c}0.0064^{* * *} \\
(0.000)\end{array}$ & $\begin{array}{c}0.0058^{* * *} \\
(0.000)\end{array}$ \\
\hline NE & $\begin{array}{c}0.0000^{* *} \\
(0.017)\end{array}$ & $\begin{array}{c}0.0000^{* *} \\
(0.013)\end{array}$ & $\begin{array}{l}0.0000^{*} \\
(0.053)\end{array}$ \\
\hline $\operatorname{lnMG}$ & $\begin{array}{l}0.0018 \\
(0.894)\end{array}$ & $\begin{array}{c}-0.0105 \\
(0.475)\end{array}$ & $\begin{array}{c}0.0264^{*} \\
(0.051)\end{array}$ \\
\hline Constant & $\begin{array}{c}15.3152^{* * *} \\
(0.000)\end{array}$ & $\begin{array}{c}15.0439^{* * *} \\
(0.000)\end{array}$ & $\begin{array}{c}14.4237^{* * * *} \\
(0.000)\end{array}$ \\
\hline
\end{tabular}


Table A2. Cont.

\begin{tabular}{cccc}
\hline Variables & $\mathbf{( 1 )}$ & $\mathbf{( 2 )}$ & $\mathbf{( 3 )}$ \\
\hline Observations & 144 & 135 & 126 \\
Adj. $\mathrm{R}^{2}$ & 0.9983 & 0.9984 & 0.9986 \\
\hline
\end{tabular}

Notes: The values in the parentheses are $p$-values of the coefficient. ${ }^{* * *}, * *, *$ indicates respectively the significance level of $1 \%, 5 \%$ and $10 \%$.

Table A3. The results of the hysteresis effect analysis (Eastern Region).

\begin{tabular}{|c|c|c|c|}
\hline Variables & (1) & (2) & (3) \\
\hline $\ln E$ & $\begin{array}{c}0.0795^{* *} \\
(0.039)\end{array}$ & $\begin{array}{c}0.0725^{* *} \\
(0.015)\end{array}$ & $\begin{array}{c}0.0707^{*} \\
(0.061)\end{array}$ \\
\hline L. $\ln E$ & $\begin{array}{c}0.0154^{*} \\
(0.081)\end{array}$ & $\begin{array}{c}0.0230^{* *} \\
(0.047)\end{array}$ & $\begin{array}{c}0.0116^{*} \\
(0.059)\end{array}$ \\
\hline L2. $\ln E$ & & $\begin{array}{l}0.0036 \\
(0.959)\end{array}$ & $\begin{array}{l}0.0042^{*} \\
(0.051)\end{array}$ \\
\hline L3. $\ln E$ & & & $\begin{array}{l}0.1365 \\
(0.140)\end{array}$ \\
\hline $\ln L$ & $\begin{array}{c}-0.1811 \\
(0.187)\end{array}$ & $\begin{array}{c}-0.1965 \\
(0.213)\end{array}$ & $\begin{array}{c}-0.2148 \\
(0.160)\end{array}$ \\
\hline $\ln K$ & $\begin{array}{c}0.3449^{* * *} \\
(0.000)\end{array}$ & $\begin{array}{c}0.3302^{* * * *} \\
(0.001)\end{array}$ & $\begin{array}{c}0.3435^{* * *} \\
(0.001)\end{array}$ \\
\hline $\ln R D$ & $\begin{array}{c}0.0268^{*} \\
(0.064)\end{array}$ & $\begin{array}{l}0.0235 \\
(0.210)\end{array}$ & $\begin{array}{l}0.0055 \\
(0.826)\end{array}$ \\
\hline $\operatorname{lnIT}$ & $\begin{array}{c}0.0595^{* * *} \\
(0.003)\end{array}$ & $\begin{array}{c}0.0552^{* * * *} \\
(0.009)\end{array}$ & $\begin{array}{c}0.0647^{* * * *} \\
(0.002)\end{array}$ \\
\hline $\ln E C$ & $\begin{array}{c}0.0423^{* *} \\
(0.043)\end{array}$ & $\begin{array}{l}0.0414^{*} \\
(0.054)\end{array}$ & $\begin{array}{c}-0.0302 \\
(0.275)\end{array}$ \\
\hline IS & $\begin{array}{l}0.0032 \\
(0.272)\end{array}$ & $\begin{array}{l}0.0040 \\
(0.372)\end{array}$ & $\begin{array}{l}0.0031 \\
(0.533)\end{array}$ \\
\hline NE & $\begin{array}{c}0.0003^{* *} \\
(0.049)\end{array}$ & $\begin{array}{l}0.0003^{*} \\
(0.057)\end{array}$ & $\begin{array}{c}0.0004^{* *} \\
(0.032)\end{array}$ \\
\hline $\ln M G$ & $\begin{array}{c}-0.0034 \\
(0.844)\end{array}$ & $\begin{array}{c}-0.0137 \\
(0.545)\end{array}$ & $\begin{array}{c}-0.0279 \\
(0.382)\end{array}$ \\
\hline Constant & $\begin{array}{c}9.6280^{* * *} \\
(0.000)\end{array}$ & $\begin{array}{c}9.8626^{* * *} \\
(0.000)\end{array}$ & $\begin{array}{c}8.9607^{* * * *} \\
(0.000)\end{array}$ \\
\hline Observations & 64 & 60 & 56 \\
\hline Adj. $\mathrm{R}^{2}$ & 0.9982 & 0.9979 & 0.9981 \\
\hline
\end{tabular}

Notes: The values in the parentheses are $p$-values of the coefficient. ${ }^{* * *}, * *, *$ indicates respectively the significance level of $1 \%, 5 \%$ and $10 \%$.

Table A4. The results of the hysteresis effect analysis (Western Region).

\begin{tabular}{cccc}
\hline Variables & $\mathbf{( 1 )}$ & $\mathbf{( 2 )}$ & $\mathbf{( 3 )}$ \\
\hline $\ln \mathrm{E}$ & $0.0912^{* *}$ & $0.0835^{* *}$ & $0.0805^{*}$ \\
& $(0.038)$ & $(0.043)$ & $(0.051)$ \\
L. $\ln \mathrm{E}$ & $0.0540^{*}$ & $0.0312^{* *}$ & $0.0166^{*}$ \\
& $(0.087)$ & $(0.048)$ & $(0.078)$ \\
L2. $\ln \mathrm{C}$ & & $0.0299^{*}$ & 0.0007 \\
& & $(0.084)$ & $(0.988)$ \\
L3. $\ln \mathrm{C}$ & & & 0.0259 \\
& & & $(0.466)$ \\
$\ln \mathrm{N}$ & $0.3984^{* *}$ & $0.3423^{* *}$ & $0.2784^{* * *}$ \\
& $(0.021)$ & $(0.014)$ & $(0.006)$ \\
$\operatorname{lnK}$ & $0.1472^{* * *}$ & $0.1578^{* * *}$ & $0.1721^{* * *}$ \\
& $(0.001)$ & $(0.001)$ & $(0.002)$ \\
$\operatorname{lnRD}$ & 0.0124 & 0.0174 & 0.0196 \\
\hline
\end{tabular}


Table A4. Cont.

\begin{tabular}{cccc}
\hline Variables & $\mathbf{( 1 )}$ & $\mathbf{( 2 )}$ & $\mathbf{( 3 )}$ \\
\hline \multirow{3}{*}{$\ln \mathrm{(T}$} & $(0.477)$ & $(0.196)$ & $(0.122)$ \\
& -0.0041 & -0.0051 & -0.0118 \\
$\ln \mathrm{CC}$ & $(0.669)$ & $(0.586)$ & $(0.218)$ \\
& $0.0701^{* * *}$ & $0.0659^{* * *}$ & $0.0574^{* *}$ \\
$\mathrm{IS}$ & $(0.010)$ & $(0.007)$ & $(0.011)$ \\
& -0.0012 & -0.0011 & -0.0004 \\
$\mathrm{NE}$ & $(0.667)$ & $(0.634)$ & $(0.859)$ \\
& 0.0001 & 0.0002 & 0.0000 \\
$\ln \mathrm{MG}$ & $(0.643)$ & $(0.546)$ & $(0.879)$ \\
& 0.0101 & -0.0021 & 0.0021 \\
Constant & $(0.477)$ & $(0.839)$ & $(0.862)$ \\
& $14.3587^{* * *}$ & $13.9920^{* * *}$ & $13.7108^{* * *}$ \\
Observations & $(0.000)$ & $(0.000)$ & $(0.000)$ \\
Adj. $\mathrm{R}^{2}$ & 48 & 45 & 42 \\
& 0.9995 & 0.9997 & 0.9998 \\
\hline
\end{tabular}

Notes: The values in the parentheses are $p$-values of the coefficient. ${ }^{* * *}, * *,{ }^{*}$ indicates respectively the significance level of $1 \%, 5 \%$ and $10 \%$.

Table A5. The results of the hysteresis effect analysis (Mountainous Region).

\begin{tabular}{|c|c|c|c|}
\hline Variables & (1) & (2) & (3) \\
\hline \multirow[t]{2}{*}{$\ln E$} & $0.0351^{*}$ & $0.0306^{* *}$ & $0.0203^{* *}$ \\
\hline & $(0.066)$ & $(0.036)$ & $(0.047)$ \\
\hline \multirow[t]{2}{*}{ L. $\ln E$} & $0.0099 *$ & $0.0136^{*}$ & $0.0280^{*}$ \\
\hline & $(0.072)$ & $(0.063)$ & $(0.076)$ \\
\hline \multirow[t]{2}{*}{ L2. $\ln E$} & & $0.0063^{*}$ & 0.0013 \\
\hline & & $(0.068)$ & $(0.526)$ \\
\hline \multirow[t]{2}{*}{ L3. $\ln E$} & & & 0.3740 \\
\hline & & & $(0.110)$ \\
\hline \multirow[t]{2}{*}{$\ln L$} & -0.1943 & -0.2834 & 0.3733 \\
\hline & $(0.236)$ & $(0.150)$ & $(0.184)$ \\
\hline \multirow[t]{2}{*}{$\ln K$} & $0.1751^{* *}$ & $0.1993^{* *}$ & $0.3886^{* * *}$ \\
\hline & $(0.028)$ & $(0.013)$ & $(0.000)$ \\
\hline \multirow[t]{2}{*}{$\ln R D$} & 0.0230 & 0.0160 & -0.0158 \\
\hline & $(0.122)$ & $(0.350)$ & $(0.399)$ \\
\hline \multirow[t]{2}{*}{$\operatorname{lnIT}$} & -0.0314 & -0.0227 & -0.0133 \\
\hline & $(0.306)$ & $(0.475)$ & $(0.587)$ \\
\hline \multirow[t]{2}{*}{$\operatorname{lnEC}$} & $0.1453^{* * *}$ & $0.1362^{* * *}$ & $0.0991^{* * *}$ \\
\hline & $(0.000)$ & $(0.000)$ & $(0.001)$ \\
\hline \multirow[t]{2}{*}{ IS } & $0.0138^{* * *}$ & $0.0126^{* * *}$ & $0.0059^{* * *}$ \\
\hline & $(0.000)$ & $(0.000)$ & (0.008) \\
\hline \multirow[t]{2}{*}{ NE } & $0.0012^{*}$ & -0.0009 & 0.0000 \\
\hline & $(0.089)$ & $(0.214)$ & $(0.944)$ \\
\hline \multirow[t]{2}{*}{$\ln M G$} & 0.0040 & -0.0049 & -0.0198 \\
\hline & $(0.882)$ & $(0.857)$ & $(0.318)$ \\
\hline \multirow[t]{2}{*}{ Constant } & $10.7295^{* * *}$ & $11.0915^{* * *}$ & $9.9621^{* * *}$ \\
\hline & $(0.000)$ & $(0.000)$ & $(0.000)$ \\
\hline Observations & 80 & 75 & 70 \\
\hline Adj. $\mathrm{R}^{2}$ & 0.9941 & 0.9933 & 0.9959 \\
\hline
\end{tabular}

Notes: The values in the parentheses are $p$-values of the coefficient. ${ }^{* * *}, * *, *$ indicates respectively the significance level of $1 \%, 5 \%$ and $10 \%$.

\section{References and Notes}

1. Schultz, T.W. Investment in human capital. Am. Econ. Rev. 1961, 5, 1-17.

2. Jorgenson, D.W.; Fraumeni, B.M. Investment in education and U.S. economic growth. Scand. J. Econ. 1992, 9, 51-70. [CrossRef] 
3. Benos, N.; Zotou, S. Education and economic growth: A meta-regression analysis. World Dev. 2014, 64, 669-689. [CrossRef]

4. Todaro, M.P.; Smith, S.C. Economic Development, 11th ed.; Prentice Hall: Upper Saddle River, NJ, USA, 2012.

5. Fifty students Class Scale Project means that there are no more than 50 students in a class.

6. Tail-cut Project is a way that cutting the tail of backward education makes education better to promote economic growth.

7. Hanushek, E.A.; Woessmann, L. The role of cognitive skills in economic development. J. Econ. Lit. 2008, 46, 607-668. [CrossRef]

8. Barro, R.; Sala-i-Martin, X. Economic Growth, 2nd ed.; McGraw-Hill/The MIT Press: New York, NY, USA, 2003.

9. Hassan, G.; Cooray, A. Effects of male and female education on economic growth: Some evidence from Asia. J. Asian Econ. 2015, 36, 97-109. [CrossRef]

10. Pink-Harper, S.A. Educational attainment: An examination of its impact on regional economic growth. Econ. Dev. Q. 2015, 29, 167-179. [CrossRef]

11. Teixeira, A.A.C.; Queirós, A.S.S. Economic growth, human capital and structural change: A dynamic panel data analysis. Res. Policy 2016, 45, 1636-1648. [CrossRef]

12. Yu, Z.; Zhu, N.; Baležentis, T. Impact of public education and regional economic growth in China: A shadow-price perspective. Sustainability 2017, 9, 1333. [CrossRef]

13. Schultz, T.W. Investing in people: Schooling in low income countries. Econ. Educ. Rev. 1989, 8, $219-223$. [CrossRef]

14. Denison, E.F. The Sources of Economic Growth in the United State E the Alternatires Before Us; Committee for Economic Development: New York, NY, USA, 1962.

15. William, E.; Rbelo, S. Fiscal policy and economic growth: An empirical investigation. J. Moneytary Econ. 1993, $32,417-458$.

16. Collins, S.M.; Bosworth, B.P.; Rodrik, D. Economic growth in east Asia: Accumulation versus assimilation. Brookings Pap. Econ. Act. 1996, 19, 135-203. [CrossRef]

17. Sylwester, K. Income inequality, education expenditures, and growth. J. Dev. Econ. 2000, 63, 379-398. [CrossRef]

18. Ganegodage, K.R.; Rambaldi, A.N. The impact of education investment on Sri Lankan economic growth. Econ. Educ. Rev. 2011, 30, 1491-1502. [CrossRef]

19. Mercan, M.; Sezer, S. The effect of education expenditure on economic growth: The case of Turkey. Procedia-Soc. Behav. Sci. 2014, 109, 925-930. [CrossRef]

20. Omojimite, B.U. Education and economic growth in Nigeria: A granger causality analysis. Afr. Res. Rev. 2010, 4, 90-108. [CrossRef]

21. Afzal, M.; Rehman, H.U.; Farooq, M.S.; Sarwar, K. Education and economic growth in Pakistan: A cointegration and causality analysis. Int. J. Educ. Res. 2011, 50, 321-335. [CrossRef]

22. Zhang, C.; Zhuang, L. The composition of human capital and economic growth: Evidence from China using dynamic panel data analysis. China Econ. Rev. 2011, 22, 165-171. [CrossRef]

23. Tsamadias, C.; Prontzas, P. The effect of education on economic growth in Greece over the 1960-2000 period. Educ. Econ. 2012, 20, 522-537. [CrossRef]

24. Qadri, F.S.; Waheed, A. Human capital and economic growth: A macroeconomic model for Pakistan. Econ. Model. 2014, 42, 66-76. [CrossRef]

25. Jalil, A.; Idrees, M. Modeling the impact of education on the economic growth: Evidence from aggregated and disaggregated time series data of Pakistan. Econ. Model. 2013, 31, 383-388. [CrossRef]

26. Woo, Y.; Kim, E.; Lim, J. The impact of education and R\&D investment on regional economic growth. Sustainability 2017, 9, 676.

27. Mariana, D.R. Education as a determinant of the economic growth. The case of Romania. Procedia-Soc. Behav. Sci. 2015, 197, 404-412. [CrossRef]

28. Lin, T.C. Education, technical progress, and economic growth: The case of Taiwan. Econ. Educ. Rev. 2003, 22, 213-220. [CrossRef]

29. Lin, T.C. The role of higher education in economic development: An empirical study of Taiwan case. J. Asian Econ. 2004, 15, 355-371. [CrossRef]

30. Lv, K.; Yu, A.; Gong, S.; Wu, M.; Xu, X. Impacts of educational factors on economic growth in regions of China: A spatial econometric approach. Technol. Econ. Dev. Econ. 2017, 23, 827-847. [CrossRef] 
31. Lucas, R.E. On the mechanics of economic development. J. Monetary Econ. 1988, 22, 3-42. [CrossRef]

32. Romer, P.M. Endogenous technological change. J. Political Econ. 1990, 98, 71-101. [CrossRef]

33. The data can be downloaded directly from the website (http://www.gdstats.gov.cn/tjsj/gdtjnj/).

34. Du, M.; Wang, B.; Wu, Y. Sources of China's economic growth: An empirical analysis based on the BML index with green growth accounting. Sustainability 2014, 6, 5983-6004. [CrossRef]

35. Lu, W.C. Electricity consumption and economic growth: Evidence from 17 Taiwanese industries. Sustainability 2016, 9, 50. [CrossRef]

36. Pearl River Delta: Guangzhou, Shenzhen, Foshan, Zhuhai, Dongguan, Zhongshan, Huizhou, Jiangmen, Zhaoqing. Eastern region: Shantou, Shanwei, Chaozhou, Jieyang.Western region: Zhanjiang, Maoming and Yangjiang. Mountainous Region: Qingyuan, Shaoguan, Heyuan, Meizhou, Yunfu.

37. Pedroni, P. Panel Cointegration, Asymptotic and Finite Sample Properties of Pooled Time Series Tests with an Application to the PPP Hypothesis; Working Papers in Economics; Indiana University: Bloomington, IN, USA, 1995; pp. 95-113.

38. Kao, C. Spurious regression and residual-based tests for cointegration in panel data. J. Econom. 1999, 90, 1-44. [CrossRef]

39. Islam, T.S.; Wadud, M.A.; Islam, Q.B.T. Relationship between education and GDP growth: A multivariate causality analysis for Bangladesh. Econ. Bull. 2007, 35, 1-7.

40. Jin, J.C. Economic research and economic growth: Evidence from East Asian Economies. J. Asian Econ. 2009, 20, 150-155. [CrossRef]

(C) 2019 by the authors. Licensee MDPI, Basel, Switzerland. This article is an open access article distributed under the terms and conditions of the Creative Commons Attribution (CC BY) license (http://creativecommons.org/licenses/by/4.0/). 